\title{
河川環境の現況整備と修景整備案に対する住民の評価構造の分析 A STUDY ON THE EVALUATION STRUCTURE OF INHABITANTS
FOR PRESENT CONDITIONS AND IMPROVEMENT PLANS
OF RIVER ENVIRONMENT
}

村川三郎*, 西名大作**, 上村 嘉孝***

Saburo MURAKAWA, Daisaku NISHINA and Yoshitaka UEMURA

\begin{abstract}
The purpose of this study is to clarify the evaluation structure of inhabitants for present conditions and improvement plans of a river. We studied the relation of recreational uses, evaluations of river environment, interest in river improvement and preference for river improvement. In the three areas; the upper, middle and lower reaches of the Seno River running through the East of Hiroshima City, we carried out the survey using questionnaires with the six pictures of present conditions and the ten kind of improvement plans for the river. As the results, we showed that the inhabitants having high evaluation for existing river environment prefer artificial improvement plans and having low evaluation prefer natural conditions.
\end{abstract}

\section{Keyward : Evaluation of River Environment, Improvement Plan of River Environment, Landscape Evaluation, Inhabitant's Perception Survey, River in Urban Area 河川環境評価, 河川環境整備案, 景観評価, 住民意識調查, 都市内河川}

\section{1. 序}

過密化した都市内において，河川空間は残された数少ない自然空 間であり，居住環境の快適性を高める貴重な構成要素として位置づ けられる。近年の河川空間の整備・計画においては，治水・利水と いった側面に加え，住民が河川を身近に感じたり，利用したりする ことのできる親水性を重視した整備や，生態系の保全を重視した近 自然型整備が実施されるようになってきているが，これらの整備は， それまでの河川と住民との関わりの在りようについて充分に配慮し， 各地域, 各河川の特徴に応じて行う必要がある。

このような観点から筆者らは，住民の河川に対する認識・接触・ 利用などの様々な特性と, 河川整備に対する選好との関連について 明らかにするため, 都市内中規模河川を対象に, 環境保全や利用適 用性などの側面で内容を異にする整備案を周辺住民に呈示して評価 を求める意識調査を行い，分析結果を報告している”。

しかしながら，調査対象とした河川では，現在，親水的側面から 種々の整備が進展している。整備以前に実施した上述の調査では, 実際の整備に対する利用・接触の経験をもたない住民によって整備 案の評価が行われていることから，代表的な現況整備に対する住民 の評価を改めて明らかにしておくことは重要と考えられる。

加えて，現況整備に対する選好を，属性や河川への関心などと同
様の個人特性としてとらえ, 修景整備案に対する選好傾向を検討す ることにより，河川整備に対する住民の意識構造のより詳細な把握 が可能となる。どのような住民がどのような河川空間を要求し，ど のような整備を望んでいるのかを，現況整備に対する選好という新 たな視点から検討することによって，河川整備計画を策定する場合 に，住民の河川との関わりや整備に対する要望を理解し，それらを 計画に反映させる上で有用な資料が得られるものと考えられる。

そこで本論文では, 親水的な整備が行われた上述の河川の周辺住 民を対象に, 現況の河川整備, 複数の河川構成要素の内容を操作し た修景整備案をそれぞれ呈示して評価を求める意識調查を実施し, 住民の河川との関わりと現況整備に対する選好との関連分析, 整備 案に対する選好特性に関する分析をふまえた上で雨者の比較を行い， 河川整備に対する住民の意識構造を明らかにしている。

\section{2. 調査概要}

\section{1 調查対象河川}

対象河川は広島市東部を流下する瀬野川である。瀬野川は東広島 市志和町に源を発し, 広島市安芸区, 安芸郡海田町を経て広島湾に 注ぐ流路 $22.5 \mathrm{~km}$, 流域面積 $122.2 \mathrm{~km}{ }^{2}$ の二級河川である。瀬野川と その流域に選定した上・中・下流の調查対象地域を図ー 1 に示す。
*広島大学:工学部 教授・工博

** 広島大学等学部 助教授・工博

*** 侏竹中工枒占 占修
Prof., Faculty of Engineering, Hiroshima Univ., Dr. Eng. Assoc. Prof., Faculty of Engineering, Hiroshima Univ., Dr. Eng. Takenaka Corporation, M. Eng. 


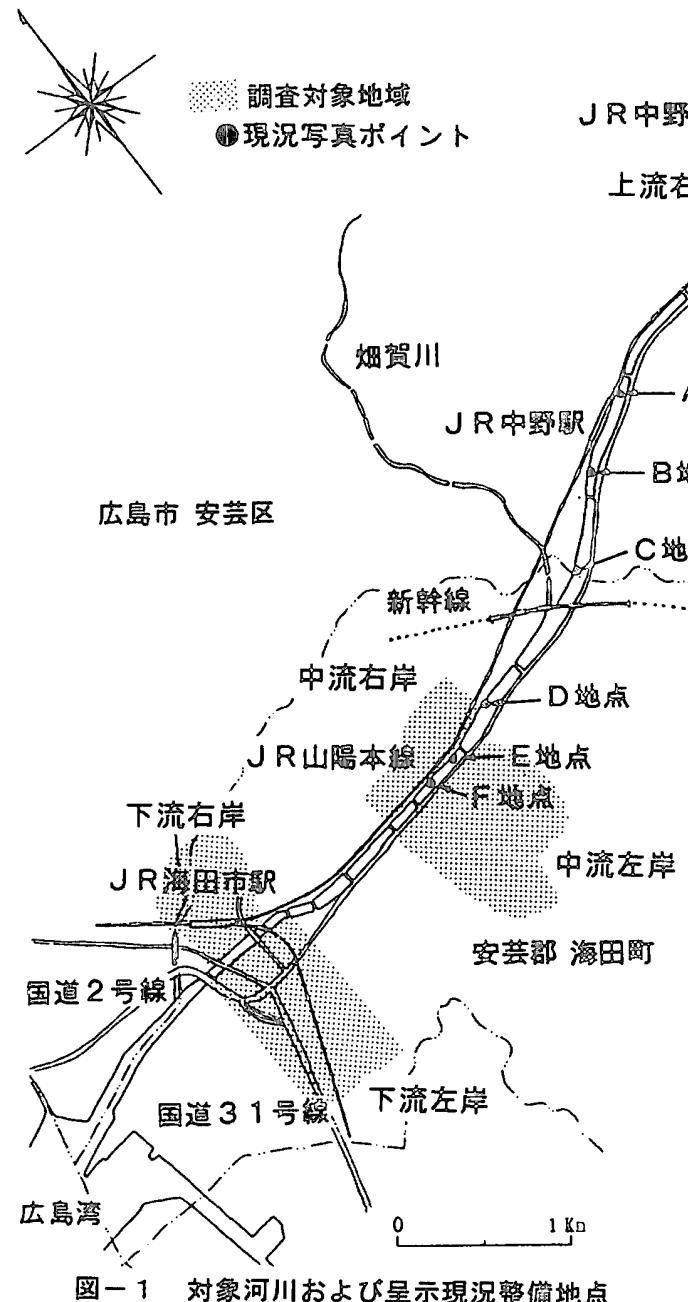

落一 1 現況警壦の内容

\begin{tabular}{|c|c|c|c|}
\hline & 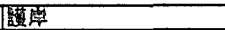 & 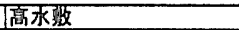 & 水際酸舜 \\
\hline 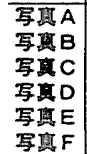 & 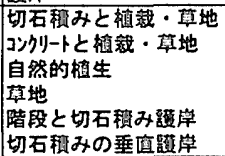 & 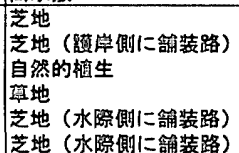 & 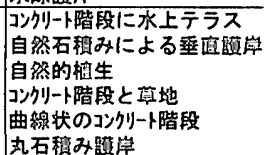 \\
\hline
\end{tabular}

\section{以下，各地域付近の河川状況について記述する。}

上流域は，両岸とも山林が多く，低水路内には比較的大きな石。 れきが多数みられ，自然的要素が多く残された地域である。右岸側 には，高水数が整備された「ほことり広場」がある。ここでは，水 際部に幅 $50 \mathrm{~m}$ 前後の階段護岸が設けてあり，水との接触が容易で ある。しかし，左岸天端には国道 2 号線があり，堤内地から河川空 間へのアクセスは安全とはいえない。

中流域は, 右岸側は高水敏が広く, 芝生の整備されている割合も 高い。この地域では, 大規模な河川環境整備が行われており, 高水 敷には，芝生による整備と併せて幅約 $1.5 \mathrm{~m}$ のサイクリング用の舗 装路が敷設され，さらに舗装された広場もある。水際部には，階段 状に整備されている箇所も多く，水との接触は容易である。この地 域には，低水路内に対岸まで飛び石が設けられている箇所もあり， 子供の水遊びの利用が多く見られる。天端は公園化され，屋根付き のベンチが設置してあり，休秘などに利用されている。一方，左岸 側は，国道 2 号線の影響により，車による乗り入れ可能場所を除い
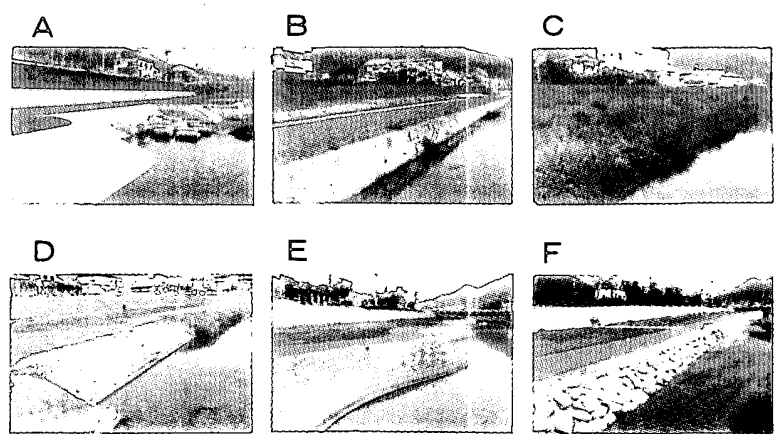

E

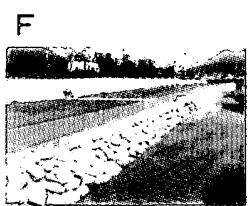

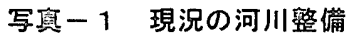

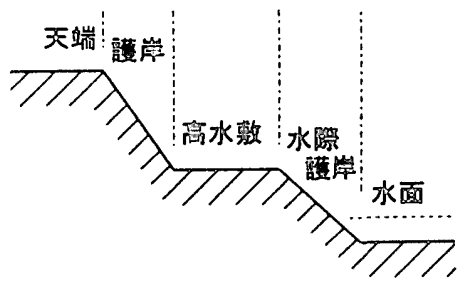

图-2 河川空間の精成要琵
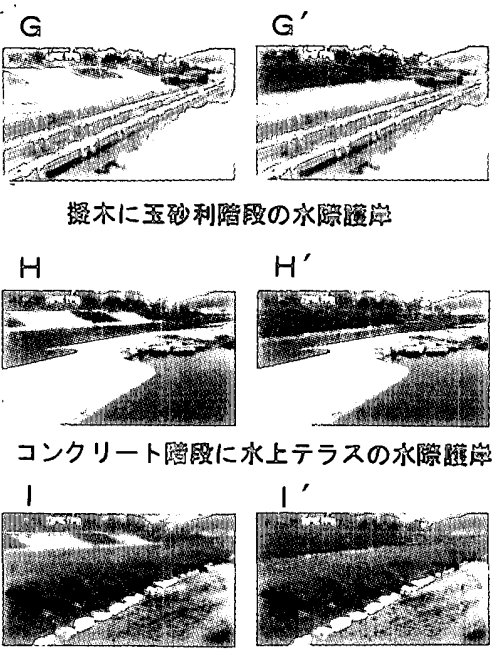

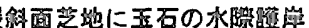

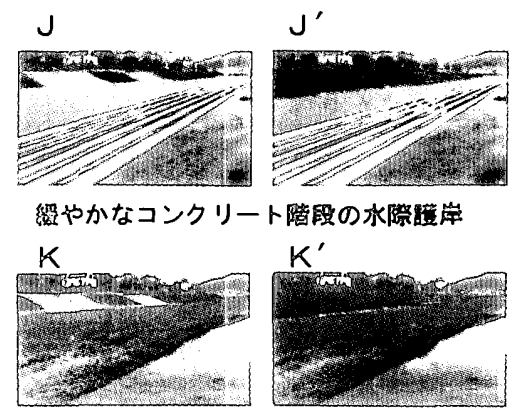

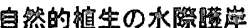

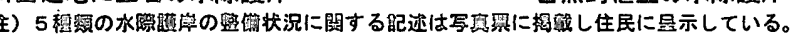
写其一2 画像如理による整備案

\section{表一2 住民意識調㚗の内容}

\begin{tabular}{|c|c|}
\hline 1）住民の居性 & 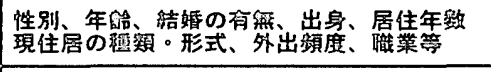 \\
\hline 2) 自宅周辺の環境評磒 & 川のきれいさ、交通盘、渌量、騷がしさ篣 \\
\hline 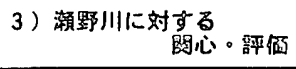 & 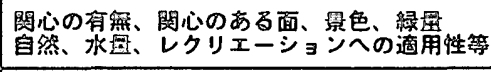 \\
\hline 4）瀬野川の利用について & 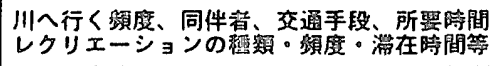 \\
\hline 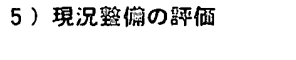 & 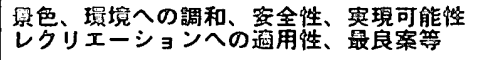 \\
\hline 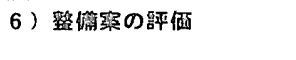 & 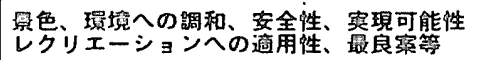 \\
\hline
\end{tabular}

酸 -3 配布・回収状況

\begin{tabular}{|c|c|c|c|c|c|c|}
\hline & & 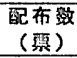 & 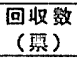 & 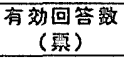 & $\begin{array}{c}\text { 有勃回答帮 } \\
(\%)\end{array}$ & 配布日 \\
\hline \multirow[t]{2}{*}{ 上流 } & 右重 & 100 & 100 & 99 & 99.0 & 12月14。15日 \\
\hline & 左肖 & 100 & 98 & 98 & 98.0 & 12月 $14 ， 15$ 日 \\
\hline \multirow[t]{2}{*}{ 中济 } & 右崩 & 90 & 90 & 87 & 96.7 & 12 月 14.15 日 \\
\hline & 左岸 & 110 & 110 & 110 & 100.0 & 12 月 $14 ， 15$ 日 \\
\hline \multirow[t]{2}{*}{ 下流 } & 右里 & 100 & 97 & 96 & 96.0 & 12月14，15日 \\
\hline & 左岸 & 100 & 100 & 100 & 100.0 & 12月 $14 ， 15 \mathrm{~B}$ \\
\hline 全 & 体 & 600 & 595 & 590 & 98.3 & \\
\hline
\end{tabular}

てアクセスは困難である。

下流域は，高密な市街化によって河川際まで建物が進出している。 両岸とも天端は交通量の比較的多い生活道路であり, 高水敭はなく, 莜岸はコンクリートで固められている。ただし， J R 海田市駅より 


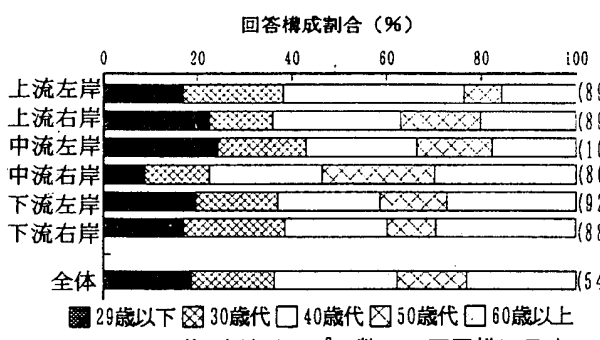

注）图中の（）内はサンプル数。以下同様に示す。 図一3 年齢

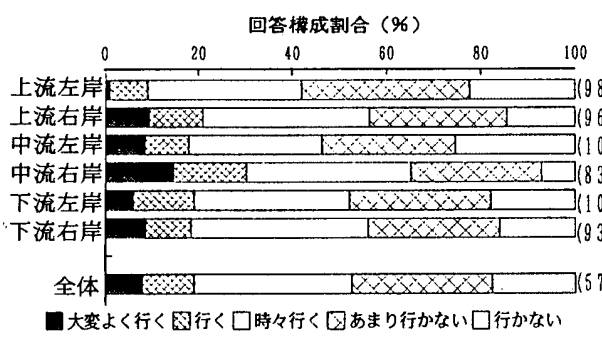

図一 5 瀬野川人行く頻度

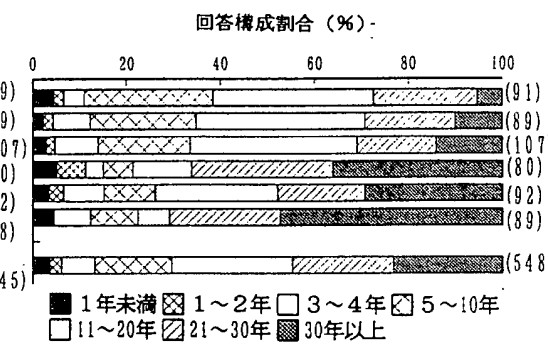

図-4 居住年数

回答楛成割合 (\%)

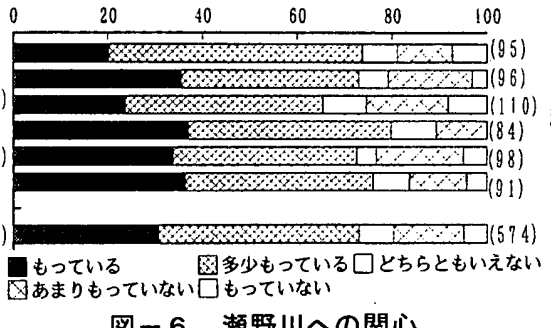

图-6 瀬野川への関心

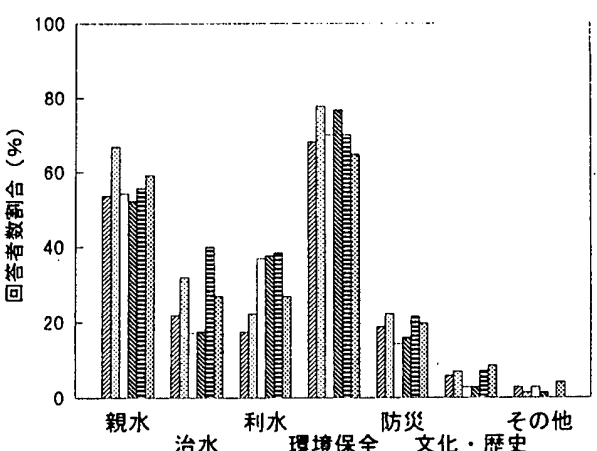

不上流左岸 国上流右岸口中流左岸 《中流右岸 曰下流左岸以下流右岸

主）関心分野の内容は調查覃では次のように眍述している。

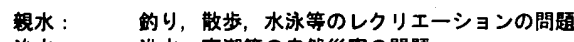
治水：洪水，高朝等の自然㜽宽の問題 利水：层業用水，工莱用水，生活用水等の利水問題

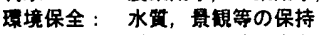

防災：避雜場所，防火带としての役揢

文化・歴史：川に関する祭り，行事，歴史，地理について

図ー7 関心のある分野
下流の左岸側には，狭小ではあるが天端に緑地帯が設けられている。 干潮域であるため，干満によって水位が大きく変動し，干潮時には 河床の砂地が現れる。

\section{2 現況整備・修䍗整備案の内容}

呈示した現況の河川整備 $(\mathrm{A} \sim \mathrm{F})$ を写真ー 1 に示す。これらは, 図一 1 中に示寸 $\mathrm{A} \sim \mathrm{F}$ の 6 地点において，低水路内より右岸側の流 軸方向を $50 \mathrm{~mm}$ レンズで撮影したものである。瀬野川に既に実在 する整備状況の中から，親水性を重視し新たに整備された地点（写 真 $\mathrm{A} \cdot \mathrm{B} \cdot \mathrm{E} \cdot \mathrm{F})$ ，従来からの整備状況を示す地点（写真 C・D） の代表的な 6 地点を選定した。これらの具体的な整備状況を, 図一 2 に示す構成要素区分に従い, 護岸, 高水敷, 水際護岸について表 - 1 に示す。親水性の高い階段や自然石による水際部, 芝生やサイ クリングロードのある高水敷など，ある程度の整備がなされた 5 地 点と，そのような人工的整備が施されていない1地点からなる。

呈示した修景整備案（ $\mathrm{G} \sim \mathrm{K}^{\prime}$ ) を写真ー 2 に示す。これらは, 堤内地側を写真 $\mathrm{F}$ の内容で統一し, 前述した護岸, 高水敷, 水際護 岸の 3 種の構成要素について修景した。なお，高水敷をいずれも芝 生による整備としたため同一とみなし, 以降では操作した構成要素 を護岸，水際護岸の 2 種として扱う蛙。これらの内容は，1989 年 に実施した河川環境整備に関する住民意識調査結果”に基づいて決 定した。緑量がある程度豊富となるように配慮し, 構成要素の形態 や素材を変化させた。整備案は, 護岸が『階段十植栽』と『植栽』 の 2 種類，水際護岸が『擬木に玉砂利階段』『コンクリート階段に 水上テラス』『緩斜面芝地に玉石の水際護岸』『緩やかなコンクリ 一ト階段』『自然的植生』の 5 種類を選定し, 両者の組み合わせに よる計 10 種類の整備案を作成した。実際の修景作業は, 現況整備 と同様に他の河川で撮影した写真を，イメージスキャナにより画像 データとしてコンピュータに取り込み，画像の合成処理によった。 完成した画像は C R T 上の画像を写真撮影することにより出力した。

\section{3 住民意識調査の概要}

現況の河川整備および修景整備案は，それらの写真を掲載した写 真票を調査票に添付して視覚的に呈示し，それらに対する評価を求 めた。調查票の内容を表一 2 に示す。
調査票の配布・回収は 1995 年 12 月 $14 ， 15$ 日に行い, 調查員の 直接訪問により依頼し, 数日留㯰きした後に再度訪問し回収した。 上・中・下流の右岸・左岸計 6 区域に対して 100 票ずつの配布を目 標とし, 総計 600 票を配布した。各調查票の配布・回収状況を表一 3 に示す。なお, 中流右岸の対象地域は他地域に比べて狭いため, 中流では右岸と左岸で配布数に多少偏りが生じている。

\section{3. 対象者の属性と河川への関わり}

\section{1 対象者の属性}

調查対象住民の属性として「年齢」「居住年数」に関する回答構 成を図ー3，4 に示す。「年龄」は，上流左岸で 40 歳代の割合が, 中流右岸で 50 歳代以上の割合が高い。「居住年数」は, 中流右岸, 下流右岸が旧山陽本線沿いの集落として発達した経緯があるため, 20 年以上の割合が高く，古くからの住民が多い。なお，男女比は， 大略 1：1で，既婚者が $80 \%$ 以上を占める。

\section{2 河川の利用・関心 ・評価}

調査結果より，住民の河川への関わりについて示す。図一 5 の 「瀬野川に行く頻度」は, 上流・中流で左岸よりも右岸のほうがよ く行く傾向にある。これは，国道 2 号線の影響と考えられ，特に， 上流左岸は山間の宅地であることから, 『大変よく行く』という回 答はほとんどみられない。図一6の「瀬野川への関心」は，全般に どの地域においても関心の程度は高いが, 左岸側よりも右岸側のほ うが関心は高い傾向を示す。図ー 7 の「関心のある分野」は複数回 答による結果を示す。ここで，環境保全面が最も高い割合を示し， 次いで親水面, 利水面, 治水面が挙げられる。

図－8の「河川環境評価」は，上・中・市流別に，20種の各評 価項目に対する住民の平均評価得点を示したものである（よい側か ら 5〜1点を付与して算定）。これより，「家庭排水による污染」 「非衛生箇所」「水量」などの瀬野川の水に関する評価は低いが, 「身近さへの欲求」「レクリェーション活用度」などの評価は高い。 しかし，「環境への満足度」の評価は中庸程度で, 河川環境に満足 しているとはいえない。地域別にみると，中流の評価が比較的高く， 市街化が進み, 親水的な整備がほとんどされていない下流では, 


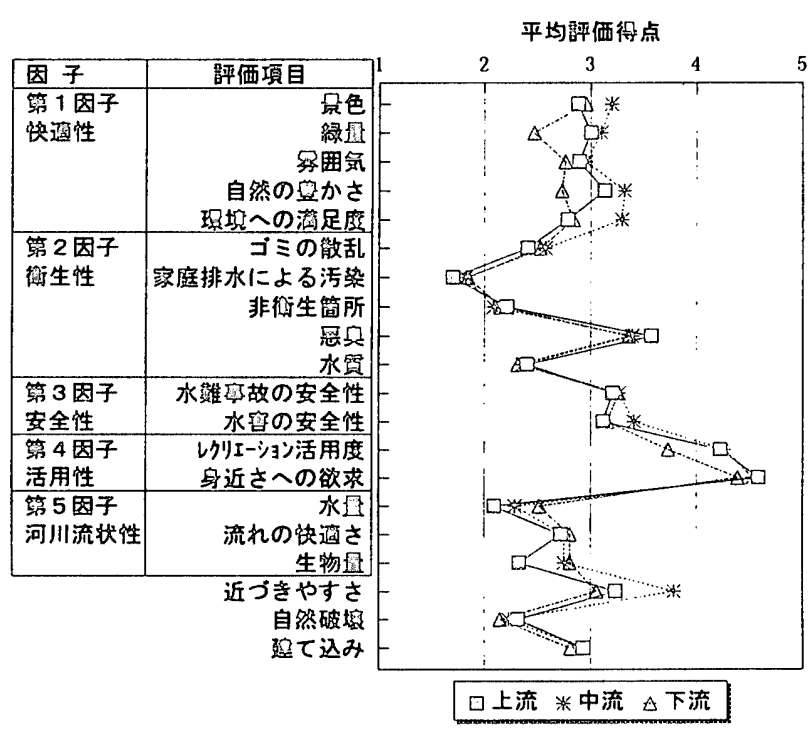

图一8 河川璬境語価

「绿量」「自然の豊かさ」「レクリエーション活用度」が上・中流 に比べて低い。また, 親水的整備が実施される以前の調㚗”之比較 するなら，「緑量」「レクリェーション活用度」において評価が高 くなっており，整備による影響がみられる。

河川環境評価 20 項目に対する個人ごとの評価得点を用いて，因 子分析（主因子法，バリマックス回転）を適用した。図ー8は，因 子数を 5 に設定した場合について，各因子ごとに分頑される項目ご とにまとめて示した。これより，第1因子は「景色」「緑量」「察 囲気」「自然の豊かさ」による、快適性』，第 2 因子は「ごみの散 乱」「家庭排水による污染」「非衛生箇所」による『衛生性』，第 3 因子は「水難事故・水害の安全性」による『安全性』，第 4 因子 は「レクリェーション活用度」，「身近さへの欲求」による『活用 性』，第 5 因子は河川の「水量」「流れの快適さ」による『河川流 状性』を示すものとしてそれぞれ解䣋した。

\section{4. 現況の河川擎偳の評価}

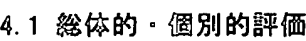

呈示した 6 種類の現況整備について，自宅近くの類野川を整備す ることを想定して，12 種の各評価項目ごとに該当すると思われる ものを複数回答により選択させた。

図一9に，主たる8 項目について，各現況整備の選択者数を全回 答者数に対する割合で上・中・下流別に示す。「瀬野川の景色とし て良い整備」では，中流で水際が曲線階段の写真 $\mathrm{E} か ゙$ 最も高い割合 を示し，上・下流では写真 $\mathrm{D} ・ \mathrm{E} ・ \mathrm{~F}$ が同程度に高くなっている。 写真D〜Fはいずれも中流の状況であり，実際にこれらを眺める機 会の多い中流の住民は，それらの経験に基づいてより差別的に判断 したものと考えられる。「整備過剩で人工的すぎる整備」では，水 際葆岸の材料がコンクリートで形態が入り組んでいる写真Aがどの 地域でも高く，次いで氷際がコンクリート階段で人為的な曲線状の 写真 $\mathrm{E} か ゙$ 高い。写真Dはコンクリートの水際階段ではあるが，その 他の部分が芝や草地で覆われているためほとんど選択されていない。 「転落事故・我難事故に対して安全な整備」では，水面まで段階的 に降りることのできる整備の評価が高くなっている。しかし，写真 Aについては水上テラスからの転落が考えられ，評洒は写真Dの階
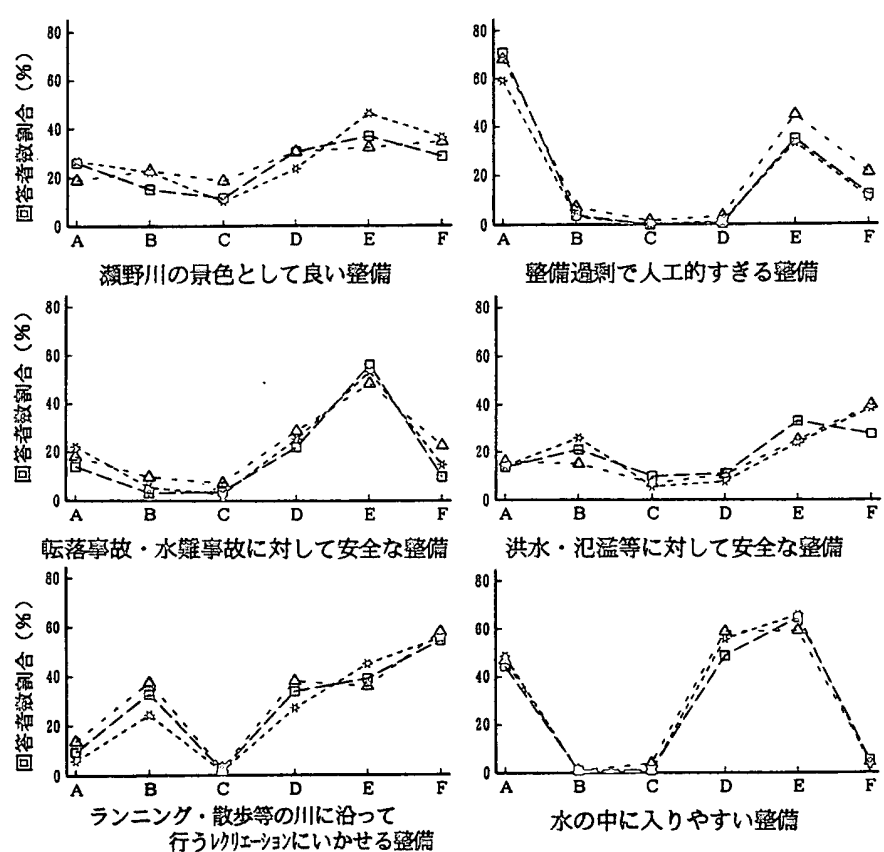

洪水・氾濫等に対して安全な監備
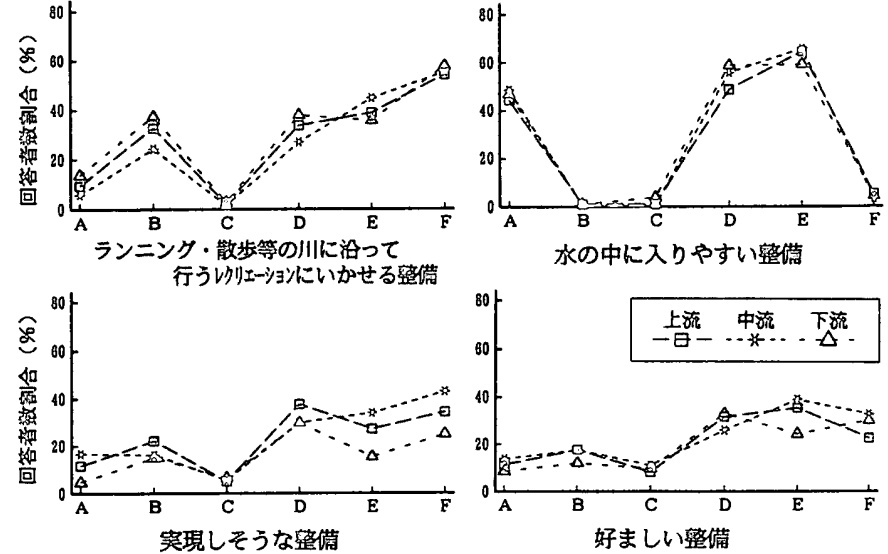

图一9現況の河川擎備に䇃する評価

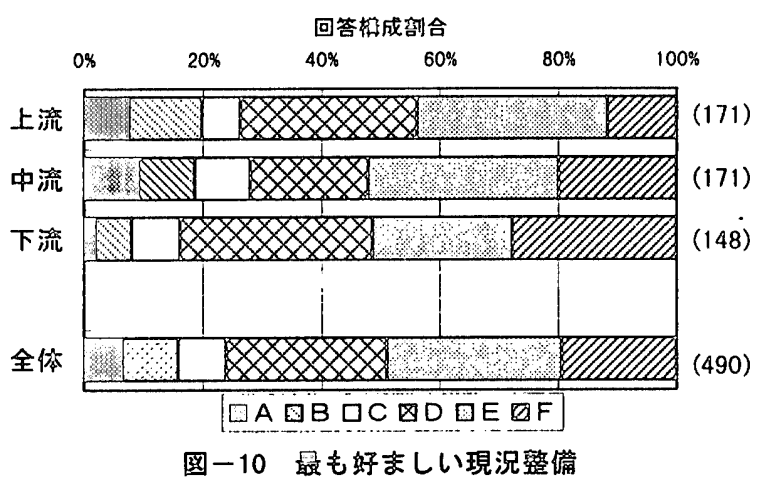

段萝岸と比べて若干低い。「洪水・氾濫等の災害に対して安全な整 備」では，讙岸，水際護岸の双方がコンクリートや石垣等によって 堅固に整備されている写真 $\mathrm{E} ・ \mathrm{~F}$ が選択されている。また，これら は，上流と中・下流で評価に若干の差異がみられ，上流では写真 $\mathrm{F}$ より写真Eの方がより多く選択されている。これは，既報でも述べ たように，安全性に関する住民の意識が上〜下流によって異なり， 洪水・氾濫の危険性が少ない上流では通水能力の高い直線状の水際 護岸より曲線状で親水性の高い水際護岸がより選択されたものと考 えられる。「ランニング・散歩等の川に沿って行うレクリエーショ ンにいかせる整備」では，高水数が広く使える写真 $\mathrm{F} ・ \mathrm{E} ・ \mathrm{~B} ・ \mathrm{D}$ が高く，特に直線的な舗装路のある写真 $\mathrm{F}$ の割合が高い。「水の中 に入りやすい整備」では，水際護岸が階段になっている整備が高く 評価されるが，それ以外はほとんど評価されない。「実現しそうな

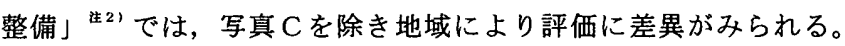
写真Cはほとんど選択されていないが，流域の人口集讂，都市化の 進展に合わせて河川整備が順次進められている瀬野川において，未 

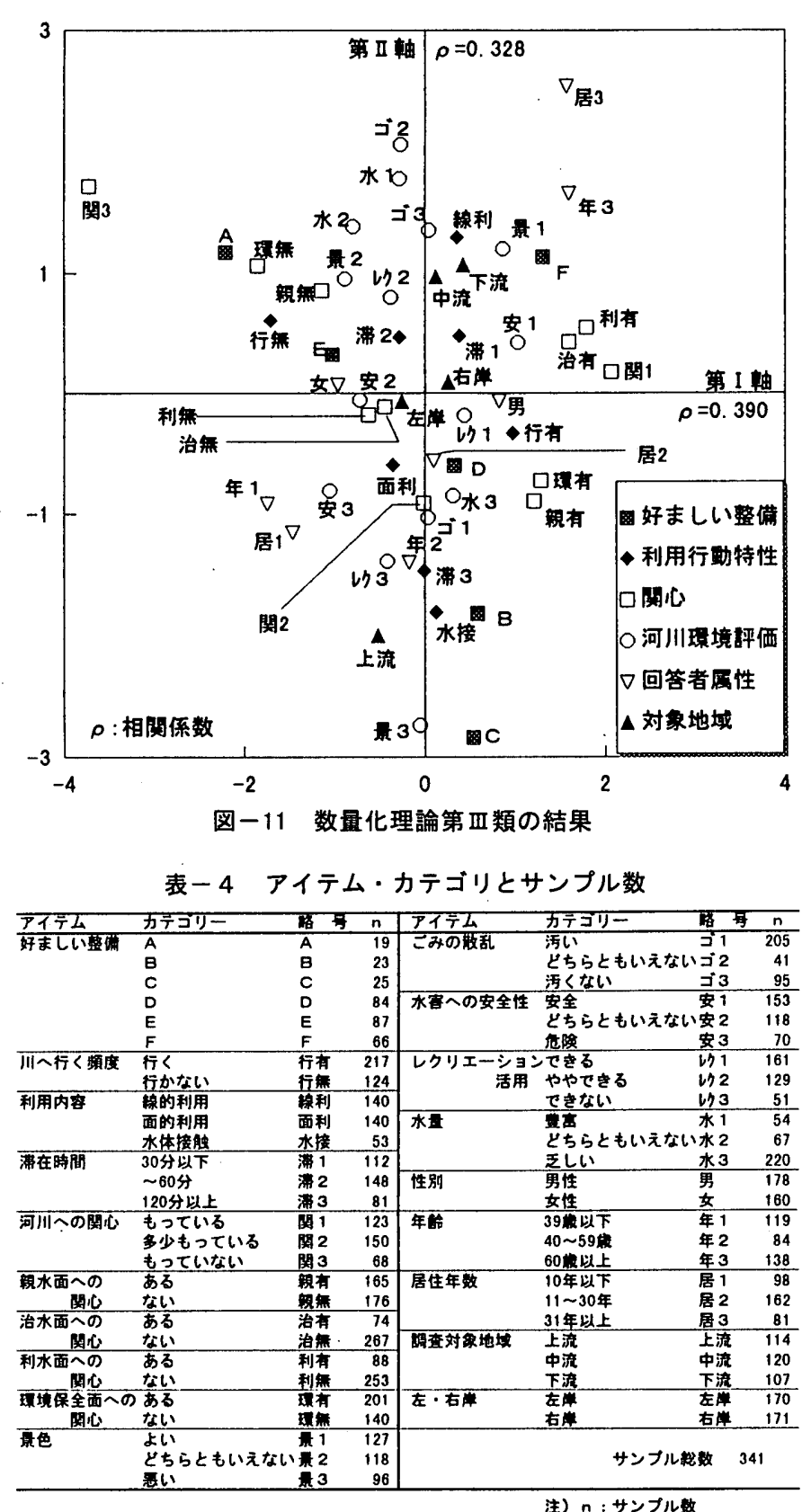

整備な自然状況に戻す方向性は住民にとって想定し難かったものと 考えられる。「好ましい整備」は，「瀬野川の景色として良い整備」 と類似した評価傾向を示し，写真 $\mathrm{D}: \mathrm{E} ・ \mathrm{~F}$ が好まれている。

なお，図示を省略した評価項目においては次のようなことがいえ る。「瀬野川の環境に調和する整備」は，写真 D・E・Fで約 30 $\%$ と同程度に評価されるが，地域により若干の差異がある。「生物 が多く棲める整備」では，写真Cが約 $80 \%$ を示し突出している。 「スポーツ・祭り・キャンプ等のレクリエーションにいかせる整備」 では，高水敷の広い写真 $\mathrm{D}$ の評価が最も高く，高水敷のない写真 $\mathrm{C}$ は「ランニング・散歩等の川に沿って行うレクリエーションにいか せる整備」と同様にほとんど評価されない。「釣り等のレクリェー ションにいかせる整備」では，水際護岸が階段状の写真 $\mathrm{A} \cdot \mathrm{D} \cdot \mathrm{E}$ が高い評価となっている。

図一10に「最も好ましい現況整備」を示す。全体で見ると，写真 $\mathrm{D} \cdot \mathrm{E} \cdot \mathrm{F} か ゙$ 好まれており, 水際が極めて直線的で過度に人工的な

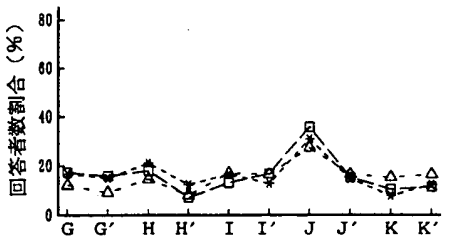

瀬野川の景色として良い整備

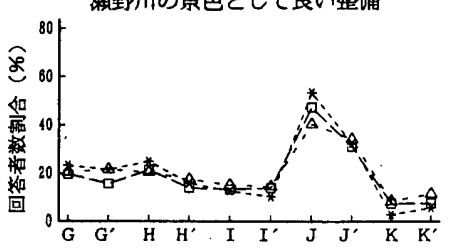

転落事故・水難事故に対して安全な整備
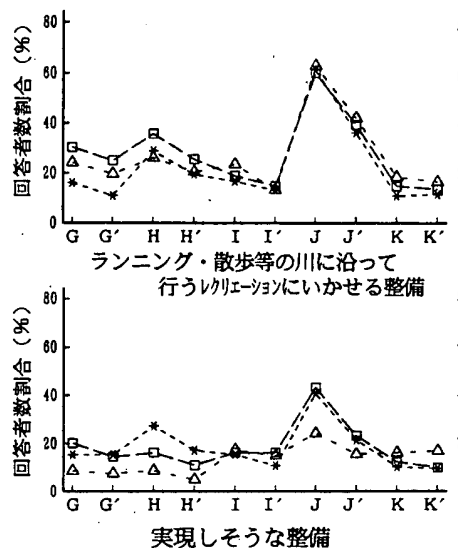

実現しそうな整備

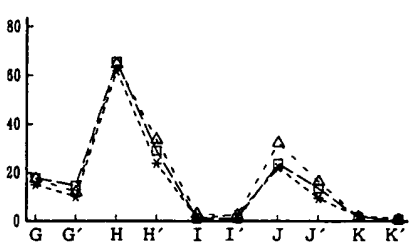

整備過剩で人工的すぎる整備

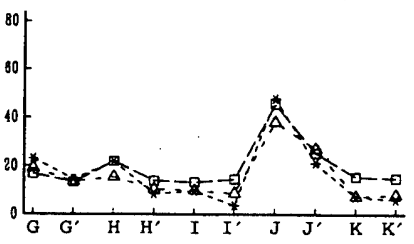

洪水・氾濫等に対して安全な整備

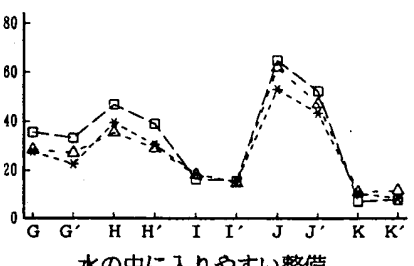

水の中に入りやすい整備

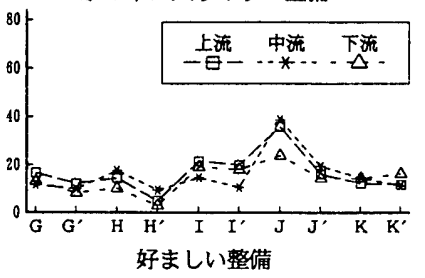

図一12 修景整備案に対する評価

整備や，高水敷全体が自然植生に覆われ著しく自然的な整備は避け られ，ある程度人工的な整備が好まれることがわかる。また，写真 Fは，地域により差異がみられ，下流の割合が高いが，これには前 述した事故や災害に対する安全性評価の影響も考えられる。

\section{2 整備の選好と河川への関わりとの関連}

最も好ましい現況整備と河川の利用行動・関心・評価および属性 との相互関連を把握するため, 数量化理論第正類による分析を行っ た。河川環境評価からのアイテムは，3.2の因子分析による抽出 5 因子において因子負荷量の最も高い項目をそれぞれ用いた。カテゴ リ区分は, 各カテゴリのサンプル数に著しい偏りが生じないように 配慮した。使用項目の内容, カテゴリ区分, サンプル数, 図中での 略号を表 -4 に, 第 I 軸・第I軸のカテジリの布置を図一11に示す。

第 I 軸では, 「瀬野川への関心」，関心のある分野との関連が高 く, 正側に関心あり，負側に関心なしのカテゴリが布置されている ことから, 瀬野川に対する関心の程度を示す軸と解釈することがで きる。この軸には，「年齢」「居住年数」のアイテム・カテゴリが 順に布置され，「瀬野川へ行く頻度」の布置から, 若年層よりも高 齢者のほうが, また, 河川に行かない人よりも行く人のほうが, 河 川に対する関心の高いことがわかる。「好ましい整備」とあわせて 考えると, 関心の薄い若年層が写真 $\mathrm{A} \cdot \mathrm{E}$ といった階段状の水際護 岸で, 形態的に変化に富んだ整備を好み, 関心の高い高齢者が写真 Fのような步きやすい直線的な舗装路のある整備を好むといえる。

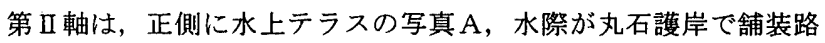

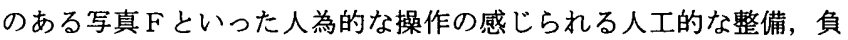
側に未整備な自然状況の写真 $\mathrm{C}$, 自然石の水際護岸の写真 $\mathrm{B}$ のよう な人為を感じさせない落ち着いた様相の整備が布置されており, 整 


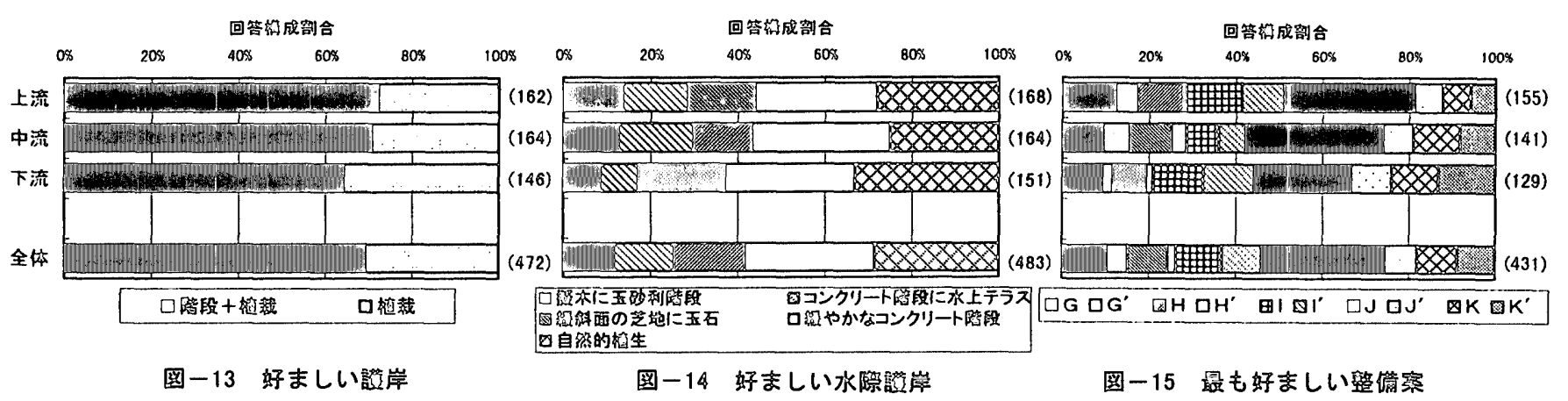

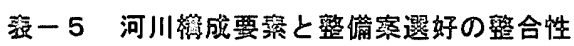

\begin{tabular}{|c|c|c|c|c|c|c|c|c|c|c|c|c|}
\hline 豕際譙岸 & 茴岸 & G & $\mathrm{G}^{\prime}$ & $\mathrm{H}$ & $\mathrm{H}^{\prime}$ & 1 & $I^{\prime}$ & $J$ & $J^{\prime}$ & $\bar{k}$ & $\mathrm{~K}^{\prime}$ & ift \\
\hline 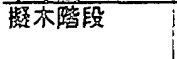 & $\begin{array}{l}\text { 階段 } \\
\text { 维唋 }\end{array}$ & $\begin{array}{c}19(51.0) \\
3(25.0)\end{array}$ & $\begin{array}{l}6(16.2) \\
8(667)\end{array}$ & $1(2.7)$ & & $2(5.4)$ & & $\begin{array}{l}5(13.5) \\
1(8.3)\end{array}$ & $3(8.1)$ & $1(2.7)$ & & $\begin{array}{l}37 \\
12\end{array}$ \\
\hline 水上テラス & 憵段 & $6(13.0)$ & & $21(457)$ & $3(6.5)$ & & & $10(21.7)$ & $3(6.5)$ & $1(2.2)$ & $2(4.3)$ & 46 \\
\hline & 笾裙 & $1(20.0)$ & & $1(20.0)$ & & $1(20.0)$ & $1(20.0)$ & $1(20.0)$ & & & & 5 \\
\hline 綑斜面芝恣 & 䉥段 & $1(2.6)$ & & $3(7.9)$ & & $20(52.6)$ & $5(13.2)$ & $5(13.2)$ & & $2(5.3)$ & $2(5.3)$ & 38 \\
\hline & 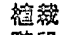 & $1(4.3)$ & & & $1(4.3)$ & $5(21.7)$ & $16(609)$ & $1(4.3)$ & & & $1(4.3)$ & 23 \\
\hline コンクリート階段 & 管段 & $3(2.9)$ & $1(1.0)$ & $4(3.9)$ & $2(2.0)$ & $3(2.9)$ & $1(1.0)$ & 79075 & $7(6.9)$ & $2(2.0)$ & & 102 \\
\hline & 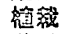 & $1(5.6)$ & & $1(5.6)$ & & & $4(22.2)$ & $2(11.1)$ & $9(50.0)$ & & $1(5.6)$ & 18 \\
\hline 自镫的植全 & 鱏段 & $1(2.4)$ & $2(4.9)$ & $2(4.9)$ & & $3(7.3)$ & $2(4.9)$ & $1(2.4)$ & $1(2.4)$ & $24(58.5)$ & $5(12.2)$ & 41 \\
\hline & 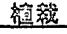 & $1(1.9)$ & $1(1.9)$ & $1(1.9)$ & 11 & $2(3.8)$ & $8(15.4)$ & $4(7.7)$ & $4(7.7)$ & $5(9.6)$ & $25(48.1)$ & 52 \\
\hline 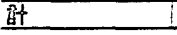 & & 37 & 18 & 34 & 7 & 36 & 35 & 109 & 27 & 35 & 36 & 374 \\
\hline
\end{tabular}

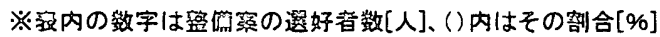

備性の軸と解貕できる。この軸には，河川舆境評価の「景色」「水 宗への安全性」「水量」のアイテム・カテゴリが順に布圆しており， 「調㚗対象地域」，関心のある分野とあわせて考えると，整備性の 高い写真を好むのは，現在の河川整備に対してある程度満足し，治 水・利水面に関心がある中流・下流の住民と考えられる。逆に整備 性の低い写真を好むのは, 現在の河川整備に対して渵足していない 親水・環境保全面に関心を有する上流の住民と考えられる。

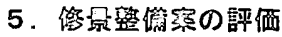

\section{1 総体的。個別的語価}

現況の河川整備に関する評価と同様に自宅近くの瀬野川を整備す ることを想定して, 呈示した 10 種類の整備案について, 各評価項 目ごとに該当すると思われるものを複数回答により選択させた。

図一12に，図一 9 と同様に主な 8 項目について，各整備案の選択 者数を全回答者数に対する割合で上・中・下流別に示す。「類野川 の景色として良い整備」では，緩やかなコンクリート階段の水際諹 岸で, 落岸が『階段十植裁』の写真 Jの割合が比較的高いのに対し

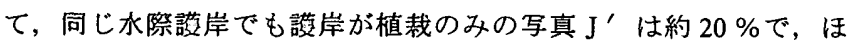
かの整備案と同程度の選択割合を示す。「整備過剩で人工的すぎる 整備」では，コンクリートで整備されている写真 $\mathrm{H} ・ \mathrm{H}^{\prime}$ 。J の割 合が高い。ほとんど選択されていない，水際萑岸が『緩斜面の芝地

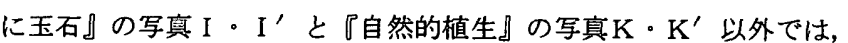
同じ永際諮岸の場合, 護岸が『階段十植裁』のほうが高くなってい る。「転落息故・水難亭故に対して安全な整備」では, 水際諼岸が 『緩やかなコンクリート階段』の写真 J J J' の割合が高い。「洪 水・氾濫等に対して安全な整備」は，「転落事故・水難烹故に対し て安全な整備」と類似した評価傾向を示す。「ランニング・散歩等 の川に沿って行うレクリエーションにいかせる整備」では, 高水敬 の広い写真 Jが高い割合を示し，いずれの水際詨岸でも，曚岸が 『階段十植裁』であるほうが評価が高い。なお，『擬木に玉砂利階 段」の写真 $\mathrm{G} ・ \mathrm{G}^{\prime}$ では, 上・中・下流で評価に差異がみられる。
「水の中に入りやすい整備」では, 水際護岸が階段状の整備案で評 価が高い。「実現しそうな整備」では, コンクリート階段の写真 J の割合が上・中流で高いが，下流ではそれほど高い值を示さない。 「好ましい整備」は「㖽野川の景色として良い整備」と穎似した評 価傾向を示し，写真 Jが最も高い。

なお，図示を省略した評価項目においては次のようなことがいえ る。「瀬野川の環境に調和する整備」は，「瀬野川の景色として良 い整備」と類似した評価傾向を示すが，写真Hにおいて地域による 差異がみられ，中流の評価が高くなっている。「生物が多く娈める 整備」では, 写真 $\mathrm{K}^{\prime}$ が約 $80 \%$, 写真 $\mathrm{K}$ が約 $60 \%$ と水際绫岸が 『自然的植生』の写真の評価が高く, 次いで写真 I' 。 I が約 20 \%の割合を示すが，そのほかの整備案はほとんど選択されていない。 「スポーツ・祭り・キャンプ等のレクリエーションにいかせる整備」 では, 写真 J が最も高い割合を示し, 水際護岸が同じ場合, 讙岸が 『階段十植裁』のほうが高くなっている。「釣り等のレクリエーシ ヨンにいかせる整備」では, どの整備内容も同程度の評価を示す。

整備案を作成する上で操作した護岸について，『階段＋植裁』 『植裁』の 2 種穎の内容のうち, いずれが好ましいかを昷ねた結果 を回答構成割合として図一13に示す。いずれの地域でも『階段＋植 裁』の割合が高いが，下流は上・中流に比べて若千低くなっている。

図一14に，水際葆岸の 5 種䫛の整備内容のうち「好ましい水際落 岸」の回答構成を同様に示す。『緩やかなコンクリート階段』『自 然的植生』がどの地域でも多く選択されている。上・中流に比べて 下流では, 『擬木に玉砂利階段』『コンクリート階段に水上テラス』 が低く，『緩斜面の芝地に玉石』が比較的高い割合を示す。

図一15に，10種類の整備案のうち「最も好ましい整備案」を示す。 いずれの地域でも，写真 J が最も高い割合を示し，ある程度人工的 で河川までのアクセスが容易な整備が好まれていることがわかる。 図一14の「好ましい水際讙岸」では，『自然的植生』が全体で約 $30 \%$ 以上好まれているのに対し，「最も好ましい擎備案」では, 写真 $K ・ K^{\prime}$ の合計は $20 \%$ 以下となっている。これは『自然的植 


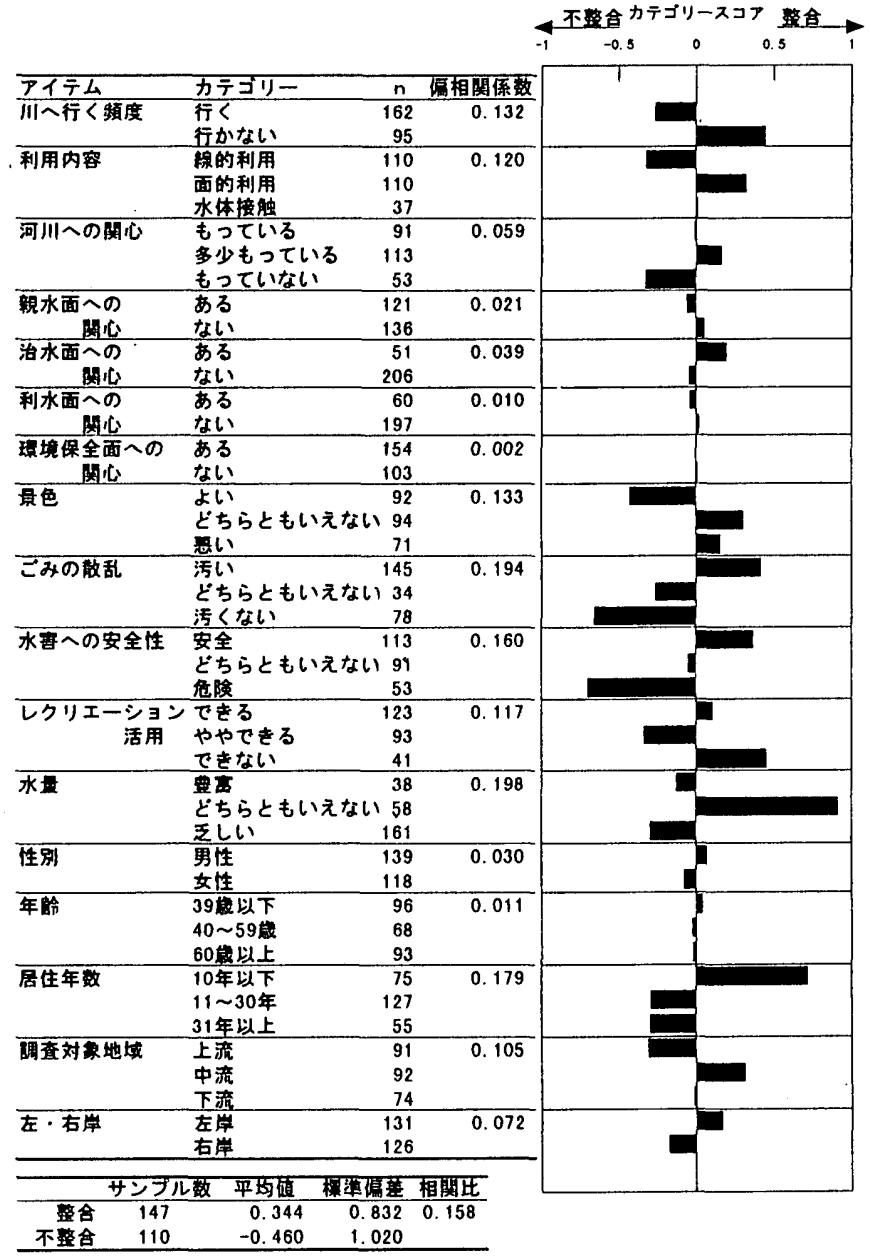

図-16 数量化理論第 II 類の結果

生』が, 水際護岸としては好まれるものの, 護岸との組み合わせに よる整備案としては，全体的な調和の面から，多少評価が低下寸る ものと考えられる。また，写真 $\mathrm{K} ・ \mathrm{~K}^{\prime}$ の割合が下流になるほど高 く, 下流は上・中流に比べ, 護岸・水際護岸の構成要素, 整備案と もにより緑量の豊富な自然的な整備を好む傾向がみられる。なお， 親水的整備が施工される以前に行った調査では，上流で自然的な整 備案，下流で人工的な整備案がある程度好まれる傾向を示した"。 しかし，施工後の下流では，これまでの治水重視の整備の実態に， 最近の社会的動向である生態系を考えた整備のあり方を重ねて，自 然的要素も取り込んだ質の高い整備を望んでいるものと推測される。

\section{2 河川構成要素と修景整備案選好の整合性}

ここでは，水際護岸と護岸の 2 種類の河川構成要素それぞれにつ いての 5 種類および 2 種類の整備内容に対する選好と, 両者の組み 合わせである整備案 $\mathrm{G} 〜 \mathrm{~K}^{\prime}$ に対する選好との関係について，両者 の一致の程度を整合性と称して記述する。

表一 5 に, それぞれの河川構成要素における各整備案の選好者数 とその割合（\%）を示す。これより，選好者数の少ない写真 $\mathrm{H}^{\prime}$ を 除き, 約半数あるいはそれ以上が構成要素と整備案の選好が整合し ている。ただし，この中で写真 $\mathrm{H}$ と写真 $\mathrm{K}^{\prime}$ の整合性は，やや低く なっている。これは，水際護岸・護岸で選好した構成要素を組み合 わせて全体的な整備案とした際に，ともにコンクリートあるいは植 生による被覆となって，極端に整備過剩，あるいは未整備的様相を
呈するために，写真 $\mathrm{H}$ よりやや人為性の劣る写真 $\mathrm{J}$ ，水際に玉石が 配された写真 $\mathrm{K}^{\prime}$ 上り若干人工的な写真 I'にそれぞれ選好が移行 したものと考えられる。また，図一15の「最も好ましい整備」で高 く選好された写真 Jは， $77.5 \%$ と整合性が高く，護岸・水際護岸 の組み合わせが全体的に調和していると評価されたと考えられる。

河川構成要素と整備案選好の整合性が，河川の利用行動・関心 . 評価および属性のいずれの項目によって規定されているかを明らか にするために，数量化理論第I類による分析を行った。結果を図一 16に示す。外的基準としては, 全く一致している場合を整合とし, そうでない場合を不整合とした。相関比は 0.158 であり, 判別的中 率は約 70 \%となる。偏相関係数の大きいアイテムを挙げるなら, 「水量」「ごみの散乱」「居住年数」などとなり, 瀬野川への関心 よりも評価のほうが整合性への要因が大きいことがわかる。アイテ ム・カテゴリから判断すると, 川へ行く頻度が高く, 現在の瀬野川 に対して景色やごみの散乱についての評価がよく, 安全性について は危険であると考えている居住年数の長い人が不整合側にあり，河 川の構成要素間の調和に考慮して全体の修景整備案を選好している と考えられる。

\section{6. 現況と修景整備案選好の関連}

図ー17に，最も好ましい現況整備として，それぞれの写真を選ん だ人が，いずれの修景整備案を選好しているかの回答者数割合を示 す。整備案の選好は, 図一12の「好ましい整備」の複数回答に上る。

写真 $\mathrm{A}$ のような整備性の高いものを選好した人は, 写真 $\mathrm{H} \cdot \mathrm{J}$ を 選んでいる。写真 $\mathrm{H}$ は, 写真 $\mathrm{A} の$ 水際護岸と同じ整備案であるため に割合が高いと考えられる。中流では, 写真 I ・ I' がやや高く選 好されている。写真 Bでは, 地域により差異があり, どの地域でも 整備案の選好が $30 \%$ 以下で, 突出して選好される整備案はみられ ない。全体が自然植生に覆われ人工的な整備の施されていない写真 Cでは，上・中・下流で特に写真 $\mathrm{K}^{\prime} \cdot \mathrm{K}$ が高く, 次いで写真 I' - I となり, 緑量が豊富な自然的な様相のものを好み, その他の整 備案はほとんど選好されていない。写真Dでは, 上流で写真 I' $\mathrm{I}$ の割合が高く, 中・下流で写真 $\mathrm{I} \cdot \mathrm{I}^{\prime}$ と写真 $\mathrm{K} \cdot \mathrm{K}^{\prime}$ が同程度

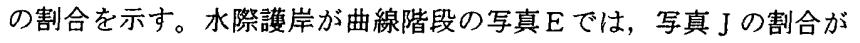
高いが，下流は上・中流に比べやや低い割合を示す。また，水際護 岸が水上テラスで護岸が『階段十植栽』の写真 $\mathrm{H}$ が写真 J に次いで 高い。これは, 曲線階段の写真 $\mathrm{E}$ を好む人が水際護岸の変化を選好 したと考えられる。写真 Fでは，写真 J が最も高い割合を示すが, 地域により差異がみられる。また写真 I が，上・下流である程度選 好されるのに対して，中流ではほとんど選好されていない。

これらの結果より, 実際に認知されている現況整備と整備案の選 好には，それぞれの整備の形態や人工的性状が類似する傾向にある ことがわかる。また，これらを4.2とあわせて考えると，写真 $\mathrm{K}$ ・ $\mathrm{K}^{\prime}$ は，写真Cを選好する現況整備に対して満足していない住民に よる割合が高く，これに対して，写真 $\mathrm{J} は ，$ 写真 $\mathrm{A} ・ \mathrm{E} ・ \mathrm{~F}$ を選好 する現況整備に対して肯定的な住民による割合が高くなるといえる。 これょり，現状の河川環境に対して満足している住民は，護岸や水 際護岸がコンクリート等ではあるものの緑量も確保されている，あ る程度人工的な整備を, 満足していない住民は, 現在の整備にさら に自然植生などを取り込むことを要求していると考えられる。 

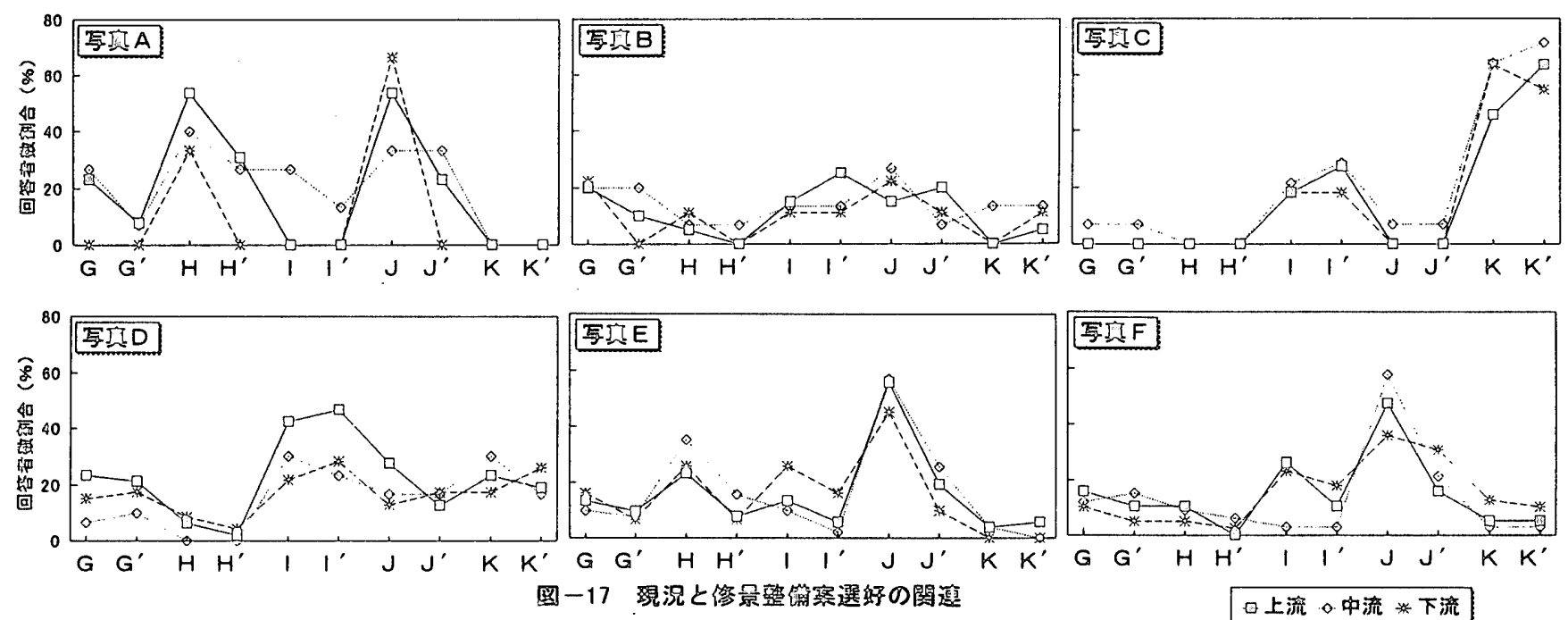

7. 結語

以上，本研究では親水的な整備が行われた河川の周辺住民を対象 として，現況河川整備・画像処理による修景整備案を呈示する住民 意識調㚗結界の分析を行った。これより得られた知見を以下に示す。 1）現況整備の総体的・個別的評価より，「好ましい整備」と 「類野川の景色として良い整備」の評価が頑似した傾向を示し，好 ましさと景色の評価に関連がみられた。また，河川整備として，人 工材料を用い人為性の高い極端に人工的な整備あるいは河川散地全 体に自然植生を保全した著しく自然的な整備は避けられ，ある程度 手の加えられた整備が好まれることを示した。これは, 算者らがこ れまでに行った調查結果と一致する”。

2) 現況整備の選好と河川への関わりとの関連分析より, 河川整 備の選好を頑型化する軸として, 関心の程度, 整備性の 2 軸を抽出 した。また，現在の河川整備に対して肯定的で治水・利水面に関心 のある中流・下流の住民は整備性の高いものを，否定的で親水・環 境保全面に関心のある上流の住民は, 自然植生や自然材料によって 渮成された整備性の低いものを選好していることを示した。

3）修景整備案の総体的・個別的評価より, 現況の評価と同様に 「好ましい擎備」と「頭野川の景色として良い整備」の評価に関連 がみられた。好ましい整備としては，コンクリート被覆は多いが緑 量も確保された，ある程度人工的で水体までのアクセス容易なもの が高く選好されている。また, 上・中流に比べて下流では, 構成要 素，整備案ともに緑量が豊富で自然的なものが選好され，治水を重 視した整備の現状に対して, 自然的要素を求めていると考えられる。 4) 河川構成要素と整備案の整合性より, 構成要素の選好の組み 合わせが極端に整備過剩になる場合は，人為性のやや劣る整備案に， 未整備的様相になる場合は，水際に玉石が使われ若干人工的な擎備 案に，選好がそれぞれ移行する傾向のあることを示した。

5) 現況整備と修景整備案の選好の関連では，それぞれの整備の 形態や人工的性状が類似する傾向にあることがわかる。また，現況 整備の評価と同様に現状の河川に満足している住民は, ある程度人 工的な整備を認めているが，渵足していない住民は，現在の整備に 対し自然植生などの自然的要素への配虑を求めていると考えられる。

\section{的辞}

本研究の一部は（財）河川琵境管理財団平成 6 年度調疽研究助成金によった。

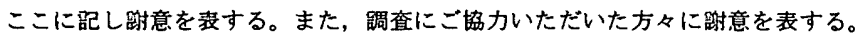

注

1） $\mathrm{G} \sim \mathrm{K}$ の水面（低水路内）の状況も呈示写真によっては多少の差異が存在 する。しかしながら，瀬野川での河川整備においては，低水路内を対象に 親水性を意図して流れ性状を变化させるような整備はほとんど実施されて おらず，また，住民には写真－2 中に付した説明を示し，䜠岸，水際讙岸 の整備であることを徹底しているため，本諭文ではこれらによる影签は些 少とみなした。

2 ）河川整借の実現性の評価には経済的側面，技術的側面など多くの锶点が存 在するが，住民には特に条件を限定せずに判断を求めた。このため，「実 現しそうな篮備」の呼価は，様々な锶点を包含する総合的評価になってい るものと考えられる。

\section{参弯文献}

1）西名大作，村川三郎：コンピュータ画像処理による河川環境整備に対する 住民意儎話価梅造の分析, 日本建築学会計画系論文報告集, No. 441, pp $15-24,1992,11$

2) 村川三郎, 西名大作 : 同上その3. 広島・攧野川における整㒉案の評価 結黑, 日本建築学会大会学術誨演梗概集 D pp. $1033-1034,1990.10$

3 ) 西名大作, 村川三郎 : 同上 その 4. 河川空間の部分的梢成要素に関する 整備案の評価結果，日本建築学会大会学術撞演梗概集 D pp. 1035-1036, 1990. 10

4 ）村川三郎，西名大作：同上その 5 . 住民の属性と河川環境整備案評価の

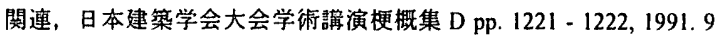

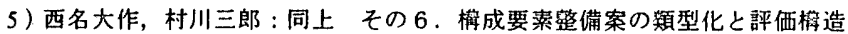
分析, 日本建築学会大会学術鹪演梗概集 D pp. 1223-1224, 1991.9

6）村川三郎，西名大作，上村嘉孝：河川境境整備に対寸る住民意識評洒權造 に関寸る研究その1．現況の整備と修景した整備案の評価結果，日本建 築学会中国・九州支部研究報告集察境系, Vol, 10, pp. 181-184, 1996.3

7) 村川三郎, 西名大作, 上村嘉考 : 同上の 2 . 現況の整備と修景整備案 の選好特性，日本建築学会中国支部研究報告集，Vol. 20, pp. $377-380$, 1997. 3

8 ）上村㗷, 村川三郎, 西名大作 : 河川環境整備に対する周辺住民の意識・ 評価橪造に関する研究 その1. 現況之整備案の評価結果, 日本建築学会 大会学術誰演梗概集 D-1 pp. 495 - 496, 1996.9

9 ) 西名大作，村川三郎，上村嘉孝 : 同上その 2, 河川に対寸る関心内容に よる評価結果の比较, 日本建築学会大会学術誨演梗概集 D-I pp. 497 - 498, 1996. 9

10）上村柺孝，村川三郎，西名大作：同上その 3 . 現況の整借之修景整備案 の選好特性, 日本建築学会大会学術講演梗概焦 D-1 pp. 451－452, 1997. 9

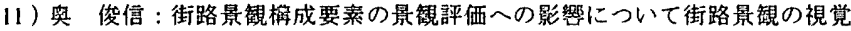
特性ならびに心理的効果に関する実喝的研究 第 2 報, 日本建築学会計画 系睮文報告集, No. 371, pp. 27 - 37, 1985.5

12）山口満，志水英樹，鉿木信弘：駅前広場における物理的要素の好ましさと 全体景锶の評価との関連梅造に関する研究，日本建築学会計画系論文集， No. 467 ,pp. $89-96,1995.1$

13 ）松浦茂樹, 島谷幸宏: 水辺空間の魅力と創造, 鹿島出版会, 1987.12 